\title{
Penerapan Perlindungan Hukum Kekayaan Intelektual Atas UMKM Melalui Peogram Sabtu Minggu Di Kota Serang
}

\author{
${ }^{1}$ Sulasno, ${ }^{2}$ Uul Nabila
}

Program Studi Ilmu Hukum, Universitas Serang Raya

\begin{abstract}
Micro, Small and Medium Enterprises (UMKM) have an important and strategic role in national economic development, UMKM in Serang City have the potential to drive the regional economy of UMKM into one of the economic pillars that drives the wheels of the economy in Indonesia. Based on data from the Serang City Industrial, Trade and Cooperatives Office, the total number in each district of the city and district of Serang reaches 10,132 UMKM, 499 MSMEs that have a small micro business license (UMK). This proves that the awareness of MSME entrepreneurs on the importance of a business permit, the importance of a brand in a product is still minimal. On this basis, we make a program called law weekend, which is a legal approach to the public or business people so that they can understand the importance of copyright, the importance of brands and contribute to trademark registration in order to protect UMKM.
\end{abstract}

Keywords: UMKM, Brands, Law Weekend

\begin{abstract}
Abstrak
Usaha Mikro kecil menengah (UMKM) mempunyai peran penting dan strategis dalam pembangunan ekonomi nasional, UMKM di Kota Serang sangatlah berpotensi dalam mendorong perekonomian daerah UMKM menjadi salah satu pilar perekonomian yang menggerakan roda perekonomian di Indonesia., berdasarkan data Dinas Industri, Perdagangan dan Koperasi Kota Serang jumlah keseluruhan disetiap kecamatan kota dan kabupaten Serang mencapai 10.132 UMKM, 499 UMKM yang mempunyai surat izin usaha mikro kecil (IUMK). Hal ini membuktikan bahwa kesadaran para pelaku usaha UMKM terhadap pentingnya sebuah izin usaha, pentingnya sebuah merek dalam suatu produk masih minim. Atas dasar itu lah kita membuat suatu program yang disebut law weekend yaitu pendekatan hukum kepada masyarakat atau pelaku usaha agar dapat mengerti pentingnya hak cipta, pentingnya merek serta ikut berkontribusi dalam upaya pendaftaran merek guna melindungi pelaku UMKM.
\end{abstract}

Kata kunci : UMKM, Merek, Sabtu Minggu

${ }^{*}$ Penulis Korespondensi

E-mail : sulasno1971@gmail.com 


\section{PENDAHULUAN}

Indonesia telah memasuki era revolusi industri 4.0. di era ini kecepatan menjadi kunci utama untuk menghadapi era revolusi. Hal ini berlaku disegala sector terutama bisnis yang digeluti oleh pelaku UMKM (Usaha Mikro Kecil dan Menengah) di tanah air. Usaha Mikro kecil menengah (UMKM) mempunyai peran penting dan strategis dalam pembangunan ekonomi nasional, kuatnya UMKM dalam membangun perekonomian Indonesia karena keunggulannya dibeberapa faktor yakni kemampuan focus yang spesifik, fleksibilitas nasional, biaya rendah, dan kecepatan inovasi. Maka dari itu UMKM menjadi salah satu pilar perekonomian yang menggerakkan roda perekonomian di Indonesia.

Akan tetapi, masih cukup banyak pelaku industry UMKM yang belum mendaftarkan kekayaan intelektual khususnya merek dagangnya dikarenakan minimnya pemahaman akan manfaat pendaftaran merek bagi industry UMKM dan terbatasnya permodalan, sehingga mereka tidak atau belum mendapatkan perlindungan hukum, sebab suatu merek dagang akan mendapatkan perlindungan jika telah melakukan permohonana pendaftaran dan sampai keluar sertifikat merek atau granted.

Begitu pula di Provinsi Banten, kalau melihat wilayah geografisnya, maka Provinsi Banten itu kaya akan Sumber Daya Alamnya, itu berarti potensi produk produk unggulan daerah khususnya UMKM baik itu dari hasil alam atau olahan sangat banyak dan berlimpah. Oleh karena Pemerintah Provinsi Banten selayaknya mengoptimalkan sumber Daya Alam tersebut menjadi berdaya guna, bermanfaat bagi orang banyak dan memberikan perlindungan hukum yang sewajarnya.
Oleh karena itu pentingnya peran pemerintah yang sangat dibutuhkan untuk mendorong dalam kegiatan UMKM agar dapat melanjutkan serta dukungan akses permodalan dan bantuan dalam mendaftarkan merek. Disamping itu juga harus adanya peran pendampingan yang dapat membantu bagi para pelaku UMKM, IKM, UKM yang ada di Kota Serang, Provinsi Banten. Selain itu masih adanya hal yang tak kalah pentingnya dengan aspek permodalan dan pendampingan namun juga adanya sosialisasi, edukasi, pemutihan, di buat peraturan secara khusus tentang peraturan yang berkaitan dengan kebijakan kekayaan Intelektual (KI). Suka tidak suka, ada atau tidak ada peran produk produk UMKM dalam menciptakan lapangan kerja dan pemerataan kesempatan cukup besar, UMKM dapat menyerap lapangan kerja mengentaskan kemiskinan dan juga sebagai penyumbang ekonomi nasional melalui penerimaan pajak, retribusi dan bentuk penerimaan lainnya.

Atas dasar itu lah kita membuat suatu program yang disebut law weekand yaitu pendekatan hukum kepada masyarakat atau pelaku usaha agar dapat mengerti pentingnya hak cipta, pentingnya merek serta ikut berkontribusi dalam upaya pendaftaran merek guna melindungi pelaku UMKM.

Ketentuan modal dasar sebesar Rp 50 juta dalam UU Nomor 40 Tahun 2007 Perseroan Terbatas dapat 'dikesampingkan' oleh para pendiri perseroan yang profilnya sesuai dengan kriteria dalam UU Nomor 20 Tahun 2008 tentang Usaha Mikro, Kecil, dan Menengah. Pemerintah memberikan kemudahan bagi pelaku usaha mikro, kecil, dan menengah (UMKM) di Indonesia yang badan hukumnya berbentuk Perseroan Terbatas (PT). 
Berdasarkan uraian diatas maka peneliti mengangkat judul penelitian "PERLINDUNGAN HUKUM TERHADAP UMKM MELALUI PROGRAM LAW WEEKEND DI KOTA SERANG MENUJU INDONESIA EMAS".

\section{METODE PENELITIAN}

Metode penelitian yang digunakan dalam penelitian ini adalah metode penelitian hukum normative empiris. Metode penelitian normative empiris merupakan penelitian melihat dari hukum yang bekerja pada segi kaidah/norma berupa peraturan perundang-undangan yang berkaitan tentang merek dengan tidak terlepas dari unsur social/empiris yakni kenyataan yang ada dimasyarakat adanya pemahaman juga perlindungan yang kurang maksimal terkait perlindungan hukum terhadap UMKM. Teknik dalam pengumpulan data dengan cara studi pustaka yaitu teknik pengumpulan dan informasi dengan menelaah sumber-sumber tertulis yang relevan dan berhubungan dengan objek yang sedang diteliti. Sehingga mampu menjawab permasalahan yang dihadapi. Analisis data dilakukan sejaca kualitatif yaitu dengan menelaah seluruh data yang tersedia kemudian dilakukan reduksi data sehingga menghasilkan penafsiran data yang sesuai dengan tujuan penelitian.

\section{PEMBAHASAN}

\section{Penerapan Perlindungan Kekayaan Intelektual terhadap UMKM melalui program Law Weekend di Kota Serang}

Penerapan merupakan sebuah tindakan yang dilakukan oleh pemerintah maupun swasta, baik secara individu maupun kelompok dengan maksud untuk mencapai tujuan yang hendak dicapai. Penerapan juga bisa diartikan sebagai pelaksanaan sebuah hasil kerja yang diperoleh melalui sebuah cara agar dapat dipraktekkan ke dalam masyarakat.
Namun demikian dalam pelaksanaan tersebut perlu adanya peryaratan yang harus di penuhi. Secara umum penerapan tersebut memiliki tiga unsur penting dan mutlak dalam menjalankannya. Adapun unsur-unsur penerapan tersebut sebagai berikut :

1. Adanya program yang dilaksanakan, Penerapan Perlindungan Hukum Kekayaan Intelektual (KI) UMKM Di Kota Serang hendaknya atas dasar program yang ada dan pelaksanaannya sesuai dengan program yang telah dibuat. antara Masyarakat Pengrajin dan penggerak Produk produk UMKM dengan pemerintah daerah (PEMKOT Kota Serang) tersebut yang berdasarkan pada peraturan perundangan yang berlaku.

2. Adanya kelompok target, yaitu masyarakat yang menjadi sasaran dan diharapkan akan menerima manfaat dari program tersebut, Secara umum masyarakat Kota Serang mempunyai pekerjaan berdagang dan sebagai penggerak produk produk UMKM. Para penggerak UMKM di kota Serang sebagian besar belum mengenal betul apa yang disebut dengan Kekayaan Intelektual (hak cipta, merek, paten, desain Industri, rahasia dagang, desain tata letak sirkuit terpadu) Sehingga kita agak susah ketika memberikan pemahaman tentang rezim $\mathrm{KI}$ apalagi yang berkaitan dengan perlindungan hukum. Namun demikian dengan adanya unsur unsur penerapan ini diharapkan program tersebut berdampak atau mempunyai konsekwensi hukum dan konsekwensi logis, artinya ada target dari program dan berfungsi serta bermanfaat 
bagi Kota Serang khususnya para penggerak produk produk UMKM baik itu secara hukum, ekonomi, social dan budaya.

3. Adanya pelaksanaan, baik organisasi atau perorangan yang bertanggung jawab dalam pengelolaan, pelaksanaan maupun pengawasan dari proses penerapan tersebut. Demikian juga penerapan peraturan perundang-undangan yang berkaitan dengan Kekayaan Intelektual (KI) beserta pelindungannya. Penerapan akan berjalan dengan baik dan dapat tepat sasaran apabila perencanaan yang matang yang diwujudkan dalam sebuah program. Kemudian program tersebut dilaksanakan atau diterapkan sesuai dengan peraturan yang berlaku.

4. Sehubungan dengan dinamika dalam penerapan perlindungan hukum kekayaan Intelektual terhadap UMKM di kota Serang, maka peneliti mencoba untuk mengadakan dan melakukan penelitian dengan fok us pada produk produk UMKM yang diselenggarakan pada hari sabtu dan minggu. Kenapa sabtu minggu ? pada saat itu para penggerak produk produk UMKM tersebut memasarkan produknya di sepanjang jalan yang ada di dekat ramayana, alun alun kota serang, sepanjang jalan Diponegoro dan di sekitar alun alun. Dengan melihat fenomena seperti itu maka timbul penulis untuk menelitinya. Program law weekend di ambil dari 2 suku kata law yang berarti hukum dan weekend yang berarti mingguan jadi program Sabtu Minggu adalah program penelitian sekaligus pengabdian hukum yang dilakukan sabtu dan minggu, yang disibukkan dengan berbagai macam aktivitas, maka pada hari sabtu dan minggu kita memanfaatkan waktu libur untuk melakukan penelitian sekaligus memberikan edukasi terhadap para pedagang, penggerak produk produk UMKM di wilayah kota serang.

5. Dengan program sabtu minggu ini diharapkan para penggerak produk UMKM memahami tentang arti pentingnya Kekayaan Intelektual bagi mereka. Mereka di berika pemahaman yang berkaitan dengan hak cipta, merek, paten, rahasia dagang, DTLST, Disain Industri, EBT, Pengetahuan Tradisional, Indikasi Geografis, termasuk perlindungan hukumnya, tidak lupa juga fungsi hukum dan tujuan hukum. Hukum bertujuan antara lain memberikan perlindungan kepada masyarakat yang berada pada posisi yang lemah, baik lemah secara sosial, politik maupun ekonomi. Perlindungan hukum dalam tulisan ini difokuskan pada aspek ekonomi, khususnya menyangkut dengan keberadaan usaha kecil dalam menghadapi persaingan bebas. Dari aspek filsafat hukum tujuan dari perlindungan kepada usaha kecil adalah dalam upaya mewujudkan keadilan ekonomi, melalui pemerataan kesempatan berusaha. Keadilan merupakan tujuan hukum yang paling esensial. Menurut anggapan umum makna hukum ialah mewujudkan keadilan dalam hidup bersama. Hukum yang berfungsi sebagai alat perekayasa sosial diharapkan dapat mengubah keadaan yang lebih baik terhadap 
kelompok yang kurang beruntung (usaha kecil).

6. Hukum tidak hanya berperan untuk menjamin adanya kepastian dan ketertiban semata, sebagaimana halnya konsep Negara penjaga malam. Akan tetapi hukum juga harus berfungsi untuk mempercepat proses pembangunan nasional. Menurut Mochtar Kusumaatmadja, hukum diharapkan berfungsi lebih daripada sekedar itu, yakni dapat sebagai "sarana pembaharuan masyarakat" atau "sarana pembangunan" dengan pokokpokok pikiran sebagai berikut "hukum merupakan "sarana pembaharuan masyarakat" didasarkan kepada anggapan bahwa adanya keteraturan atau ketertiban dalam usaha pembangunan dan pembaharuan itu merupakan suatu yang diinginkan atau dipandang (mutlak) perlu.

7. Tujuan utama dalam menjalankan bisnis adalah untuk mencari keuntungan. Untuk memperoleh keuntungan tersebut pelaku bisnis harus bersaing dengan pelaku bisnis lainnya. Persaingan bisnis cendrung tidak sehat berdampak pada ketidakadilan distribusi pendapatan. Hal ini akibat adanya ketimpangan dalam persaingan bisnis. Untuk mencegah dan mengatasi pesaingan bisnis yang tidak sehat yang dapat merugikan usaha kecil dan konsumen, maka pemerintah perlu ikut campur mengatur agar persaingan bisnis berjalan secara fair.

Peranan pemerintah sangatlah strategis dalam menentukan arah dan kebijakan bagi pemerataan pendapatan yang adil, khususnya UMKM melalui serangkaian kebijakan publik. Kebijakan publik tersebut dapat ditempuh melalui tugas Negara sebagai legistator dan fasilitator yang dilegitimasi melalui berbagai produk hukum, seperti UndangUndang, Peraturan Pemerintah sampai peraturan daerah.

UMKM (Usaha Mikro, Kecil dan Menengah) menjadi target dalam program ini, melihat bahwa UMKM (Usaha Mikro Kecil dan Menengah) merupakan salah satu mesin penggerak pertumbuhan ekonomi Indonesia, Usaha Mikro Kecil dan Menengan (UMKM) merupakan nyawa bangsa, UMKM adalah kunci untuk mencapai Indonesia Emas. Indonesia Emas adalah sebuah kondisi saat Negara Indonesia diharapkan mampu bersaing dengan bangsa lain serta dapat menyelesaikan masalah-masalah kebangsaan seperti korupsi dan kemiskinan. Indonesia Emas diproyeksikan pada seratus tahun kemerdekaan Negara Indonesia pada tahun 2045, sumber daya manusia Indonesia merupakan salah satu faktor penting untuk mewujudkan Negara Indonesia yang adil dan makmur.

Oleh karena itu Indonesia Emas 2045 disebut sebagai jendela demografi, bonus demografi tidak selamanya membawa hal yang positif, justru bisa menjadi sebuah bencana apabila penduduk usia produktif tidak memiliki keterampilan yang mumpuni, sehingga kondisi ini meningkatkan pengangguran.umtuk menjawab tantangan pengangguran ini, peran UMKM dalam perekonomian Indonesia cukuplah besar, dengan terlihat dari besarnya populasi yang ada dan dalam penyerapan tenaga kerja.UMKM memiliki daya tahan yang lebih terhadap krisis, dibandingkan dengan perusahaanperusahaan besar yang ada, melihat sejarah ketika pada tahun 1997 saat Indonesia mengalami krisis moneter. berdasarkan data Dinas Industri, Perdagangan dan Koperasi Kota Serang, 
jumlah keseluruhan disetiap kecamatan kota dan kabupaten Serang mencapai 10.132 UMKM, 499 UMKM yang mempunyai surat izin usaha mikro kecil (IUMK) dan hanya 3 UMKM yang telah mendaftarkan merek.

Hal ini membuktikan bahwa kesadaran para pelaku usaha UMKM terhadap pentingnya sebuah izin usaha, pentingnya sebuah merek dalam suatu produk masih minim. Maka kita peneliti hadir untuk memberikan pemahaman kepada para pelaku usaha dengan cara mensosialisasikan tentang pentingnya merek, yang juga akan dibantu oleh pendampingan, ahli hukum bisnis dan kementrian hukum dan Ham, Dinas Perdagangan dan Perindustrian Kota Serang dalam upaya memberikan kesadaran kepada para pelaku usaha tersebut, serta kita ikut berkontribusi dalam upaya pendaftaran merek tersebut hingga produk pelaku usaha ini mendapatkan perlindungan hukum.

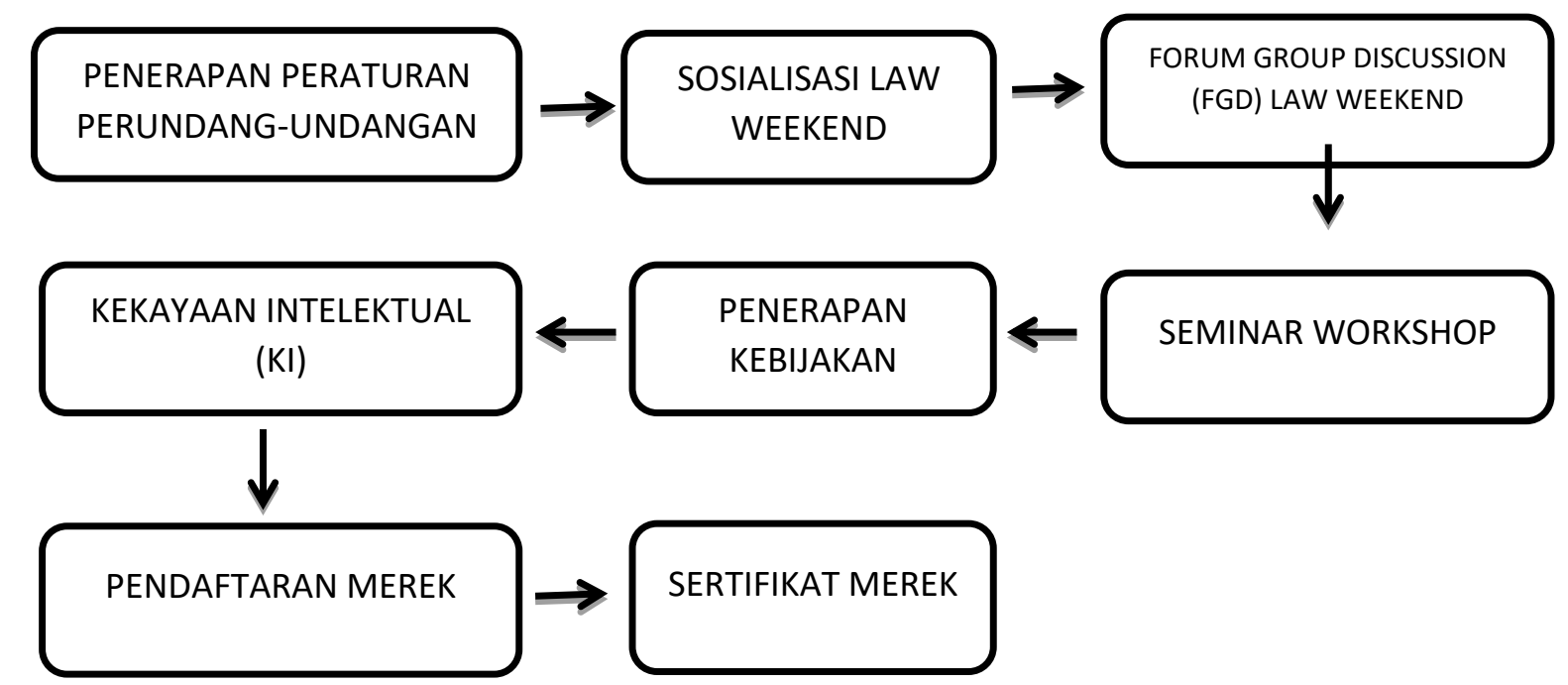

\section{Mekanisme permohonan pendaftaran merek produk-produk UMKM di Kota Serang}

Saat ini Indonesia telah masuk dalam era baru yaitu terbentuknya komunitas Masyarakat Ekonomi ASEAN (MEA) yang menjadi pasar tunggal (single market) dan tempat berproduksi bersama (production base) untuk masyarakat ASEAN dan luar ASEAN. Adanya keterbukaan dalam pasar global tersebut menuntut perlunya perlindungan terhadap produk-produk, khususnya koperasi dan Usaha Mikro Kecil dan Menengah (UMKM) agar tidak ditiru oleh pesaing lainnya. Perlindungan tersebut berupa perlindungan terhadap Hak atas Kekayaan Intelektual (HKI) atas produk dan desain, melalui diterbitkannya sertifikat HKI.

Salah satu perlindungan Kekayaan Intelektual (KI) yang penting untuk didaftarkan oleh pelaku UMKM adalah merek. Merek (branding) penting bagi UMKM agar semakin dikenal masyarakat luas dan menjadi ciri khas terhadap usahanya. Merek mempunyai beberapa fungsi, yaitu sebagai badge of origin, $a$ piece of personal property, dan sebagai cultural resource. Merek sebagai badge of origin, merupakan hak penting dalam perdagangan dan memperlihatkan hubungan erat antara barang, jasa dan orang yang mempunyai merek tersebut dengan asal barang. Sedangkan personal property, mempunyai arti bahwa merek merupakan aset bagi 
pemilik merek, sehingga pemilik merek dapat menjual merek tersebut karena memiliki nilai ekonomi. Merek sebagai cultural resource, yaitu merek dapat dikaitkan dengan budaya suatu negara.

Merek adalah sebuah simbol pembeda antara produk atau jasa, sangat banyak berbagai perusahaan atau perorangan yang sudah sangat sukses dengan merek-merek terkenal yang mereka buat atas produk atau jasa yang tentunya akan berharga jika dilabeli dengan merek terkenal.

Pendaftaran merek bagi produk produk UMKM (Usaha Mikro Kecil Dan Menengah) sekarang telah dipermudah dengan diundangkannya Undang-Undang Nomor 20 Tahun 2016 tentang Merek dan Indikasi Geografis yang diturunkan dalam peraturan pelaksanaannya melalui Peraturan Menteri Hukum dan Hak Asasi Manusia Nomor 67 Tahun 2016 tentang Pendaftaran Merek.

Permohonan pendaftaran merek dapat diajukan melalui Konsultan Hak Kekayaan Intelektual Terdaftar. Jika semua persyaratan telah terpenuhi, maka pemohon tinggal menerima tanggal penerimaan merek sebagai tanda terima permohonan. Permohonan merek tersebut akan diumumkan melalui berita resmi merek, di mana masa pengumuman akan berlangsung kurang lebih selama dua bulan.

Program pemerintah di Kota Serang Provinsi Banten terkait dengan upaya peningkatan kesadaran hukum dengan legalitas dimana UMKM (Usaha Mikro Kecil Dan Menengah) mempunyai produk yang akan mendapatkan perlindungan hukum, artinya ketika sebuah produk akan maju atau laku dipasaran tidak ada orang lain yang akan mengklaim produk atau jasa dengan menggunakan merek tersebut.
Berdasarkan data dari Dinas Perindustrian dan Perdagangan maka jumlah UMKM di kota Serang adalah Usaha Mikro : 6495, Usaha Kecil : 3595, Usaha Menengah : 222, Jumlah UKM : 10.321 Data ini diambil dari Dinas Koperasi dan UKM Provinsi Banten.

Kemudian upaya pemerintah untuk mendorong UMKM (Usaha Mikro Kecil Dan Menengah) tersebut pemerintah mengadakan sosialisasi setiap tahunnya yang bekerja sama dengan Dinas dalam hal ini Dinas Koperasi dan UMKM (Usaha Mikro Kecil Dan Menengah) disetiap Kabupaten Kota, serta selalu koordinasi dan menyelenggarakan baik itu sosialisasi, workshop maupun bimtek. Audiensinya pun para pelaku UMKM (Usaha Mikro Kecil Dan Menengah) binaan, bukan hanya pembinaan terhadap Merek tetapi halal juga perlu apalagi jika produk yang mereka buat adalah produk pangan.

Ada insentif yang diberikan pemerintah dalam pendaftaran yang berasal dari UMKM (Usaha Mikro Kecil Dan Menengah) yaitu berupa keringanan biaya, sesuai dengan Peraturan Pemerintah Nomor 28 tahun 2019 itu dinyatakan bahwasanya pendaftaran Merek PNBP (Penerimaan Negara Bukan Pajak) sekitar Rp.1.800.000 (satu juta delapan ratus) tetapi jika pemohonnya berasal dari pelaku UMKM maka dapat keringanan menjadi Rp.500.000 (lima ratus ribu), tetapi tentu saja ada syarat yang harus dipenuhi yaitu melampirkan surat keterangan dari Dinas yang dinyatakan bahwa pemohon pendaftaran Merek tersebut adalah UMKM binaan dari instansi atau dari Dinas tersebut, baik dari Dinas Koperasi dan UMKM maupun Dinas Perindustrian dan Perdagangan. Untuk sektor UMKM berada di Dinas Koperasi dan UMKM kemudian untuk IKM dikeluarkan oleh Dinas Perindustrian dan Perdagangan. Saat ini pelaku UMKM yang 
telah mendaftarkan mereknya kepada Kementrian Hukum dan Hak Asasi Manusia telah mencapai 184 yang sebagian besarnya adalah pelaku UMKM (Usaha Mikro Kecil Dan Menengah) se Provinsi Banten.

Mekanisme dalam pendaftaran merek

a) Meminta surat pengantar dari RT dan RW setempat

b) Melimpahkan surat pengantar serta berkas yang dibutuhkan dalam pendaftaran ijin usaha yang kemudian akan dikeluarkan surat keterangan usaha (SKU) oleh kecamatan.

c) Melimpahkan surat usaha serta berkas kepada Dinas Perdagangan dan Perindustrian untuk selanjutnya meminta surat pengantar yang akan ditujukan dalam pendaftaran merek kepada Kementrian Hukum dan Hak Asasi Manusia. Jika produk tersebut adalah sebuah produk pangan, pelaku diwajibkan untuk mendaftarkan Halal kepada MUI dengan meminta surat pengantar kepada Dinas Perdagangan dan Perindustrian.

d) Mendaftarkan merek dengan langsung dating ke kantor Kemenkumham atau dapat langsung mendaftarkan melalui website https://www.dgip.go.id.

Jika semua persyaratan telah terpenuhi, maka pemohon tinggal menerima tanggal penerimaan merek sebagai tanda terima permohonan. Permohonan merek tersebut akan diumumkan melalui Hal-hal yang harus dicantumkan dalam permohonan

a) Hak-hak prioritas untuk pemohon yang terdaftar di Negara lain

b) Pengumuman

c) Keberatan dan Sanggahan

d) Pemeriksaan merek e) Hak banding

Mulai per tanggal 17 Agustus 2019 pengajuan permohonan pendaftaran Kekayaan Intelektual (KI) yaitu Merek, Paten, Desain Industri) dilakukan secara online. Registrasi akun dan pengajuan permohonan pendaftaran $\mathrm{KI}$ dapat dilakukan melalui Website Memang semakin berkembang dan supaya perolehan KI di Indonesia semakin banyak maka pemerintah melalui Kdementrian Hukum Dan HAM melakukan terobosan dengan cara memberikan kemudahan kepada masyarakat untuk mendaftarkan dan melindungi KInya secara personal. Itu dilakukan dengan maksud memberikan perlindungan hukum dan supaya masyarakat Indonesia melek terhadap KI. Maka di jaman sekarang masyarakat yang ingin melindungi karya karyanya, produknnya tinggal registrasi log in dan melakukan pendaftaran. Dalam perrmohonan pendaftaran merek dengan tujuan untuk mencari perlindungan hukum dalam prakteknya tidak selalu berjalan lancer. Ada beberapa hambatan pemohon melakukan pendaftaran merek perrmohonan pendaftaran merek, sebagai berikut :

a. Masyarakat di Kota Serang secara keseluruhan belum melek terhadap Kekayaan Intelektual (KI) atau kurang kesadaran bagi mereka penggerak UMKM

b. Kurangnya Sosialisasi dari pihak terkait atau pemahaman KI perlu ditingkatkan

c. Para penggerak UMKM kota Serang masih sebatas untuk menghidupi keluarganya

d. Beaya mahal dan jangka waktu yang begitu lama, walau pendaftaran sekarang melalui atau secara online tetep saja mahal dan waktunya lama.

e. Belum terdapat Unit yang fokus mengurusi KI dan pemanfaatannya 
Dalam prakteknya ternyata permohonan pendaftaran merek itu tidak sesederhana yang ada dalam peraturan perundang-undangan, karena dalam pelaksanaannya menjadi ribet dan terkesan susah, belum bicara pembayaran, kemudian, tahapan tahapan dalam pendaftaran merek, jangka waktu, juga ada prosedur tanya jawab tentang merek dagangnya, belum juga secara online yang kelihatan mudah ?

\section{PENUTUP}

Berdasarkan rumusan

permasalahan dan dalam pembahasan

diatas maka penulis simpulkan sebagai berikut :

1. Perlindungan hukum kekayaan intelektual atas produk produk UMKM di kota Serang Provinsi Banten Diharapkan dapat menjamin kepastian hukum baik itu perlindungan hukum preventif maupun perlindungan hukum represif. Adapun penjabaran dari preventif itu mencegah supaya tidak terjadi penyimpangan, pelanggaran dalam kekayaan intelektual (Hak Cipta, Merek, Rahasia Dagang, Paten, Desain Industri, DTLST, dII). Bila dilihat dari aspek ekonomi, khususnya perlindungan tersebut menyangkut dengan keberadaan usaha kecil dalam menghadapi persaingan bebas. Masyarakat harus lebih kreatif serta berani bersaing dengan produk asing untuk itu setiap produk itu perlu perlindungan kekayaan intelektual, dengan cara pendaftaran KI tersebut. Dari aspek filsafat hukum tujuan dari perlindungan kepada usaha kecil adalah dalam upaya mewujudkan keadilan ekonomi, melalui pemerataan kesempatan berusaha. Salah satu perlindungan $\mathrm{HKI}$ yang penting untuk didaftarkan oleh pelaku UMKM adalah merek. Oleh karena itu bentuk perlindungan hukum yang kami maksud adalah mendaftarkan sebuah merek kepada kementrian hukum dan hak asasi manusia agar merek dan produk yang mereka miliki mampu terlindungi dan mencegah dari halhal yang dapat merugikan bagi para pelaku UMKM.

2. Mekanisme dalam permohonan pendaftaran merek Meminta surat pengantar dari RT dan RW setempat Melimpahkan surat pengantar serta berkas yang dibutuhkan dalam pendaftaran ijin usaha yang kemudian akan dikeluarkan surat keterangan usaha (SKU) oleh kecamatan. Melimpahkan surat usaha serta berkas kepada Dinas Perdagangan dan Perindustrian untuk selanjutnya meminta surat pengantar yang akan ditujukan dalam pendaftaran merek kepada Kementrian Hukum dan Hak Asasi Manusia. Jika produk tersebut adalah sebuah produk pangan, pelaku diwajibkan untuk mendaftarkan Halal kepada MUI dengan meminta surat pengantar kepada Dinas Perdagangan dan Perindustrian.Mendaftarkan merek dengan langsung datang ke kantor Kemenkumham atau dapat langsung mendaftarkan melalui website https://www.dgip.go.id dengan membawa syarat-syarat sesuai dengan pasal 4 Undangundang Nomor 20 Tahun 2016 Tentang Merek dan Indikasi Geografis. Jika semua persyaratan telah terpenuhi, maka pemohon tinggal menerima tanggal penerimaan merek sebagai tanda 
terima permohonan. Permohonan merek tersebut akan diumumkan melalui berita resmi merek, di mana masa pengumuman akan berlangsung kurang lebih selama dua bulan.

Saran

1. Diharapkan Pemerintah dapat memberikan perlindungan hukum secara khusus dengan membentuk perangkat hukum di tingkat daerah serta memfasilitasi, mendorong, memberikan pendampingan, mengedukasi secara rutin dan memberikan insentif insentif kepada para penggerak produk produk unggulan UMKM di Kota Serang, Provinsi Banten sehingga tujuan meningkatkan

kesejahteraan rakyatnya terwujud.

2. Bagi UMKM, IKM, UKM, dengan diberikan Program Law Week And, maka diharapkan para pengrajin, penggerak Produk produk unggulan UMKM melek akan rezim kekayaan intelektual (KI) secara umum dan segera melakukan permohonan pendaftaran $\mathrm{KI}$ secara khusus sehingga perlindungan hukum tentang Kekayaan Inteketual terwujud.

\section{DAFTAR PUSTAKA}

\section{Buku}

Didik J. Rachbini, "Ekonomi Pasar Sosial : Pilihan Ketiga

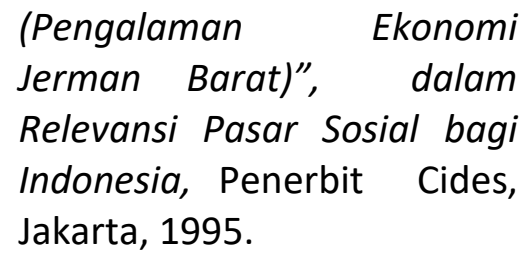

Fuady Munir. Pengantar Hukum Bisnis, PT Cipta Aditya Bakti, Bandung, 2012.

Is Muhamad Sadi, Pengantar Ilmu Hukum, KENCANA, Jakarta 2015

Lindsey, eddy, simon, tomi. HAK KEKAYAAN INTELEKTUAL: suatu pengantar. Sinar grafika. Jakarta 2006

Kusumaatmadja Mochtar, Hukum, Masyarakat, dan Pembinaan Hukum Nasional, Binacipta, Bandung, 1995.

Philipus M. Hadjon, Perlindungan Bagi Rakyang Indonesia, PT. Bina Ilmu, Surabaya, 1987.

Rahayu, Pengangkutan Orang, etd.eprints.ums.ac.id. Peraturan Pemerintah RI. 2009.

Roisah Kholis, konsep hukum hak kekayaan intelektual, STARAPRESS, Malang 2015.

\section{Saidin OK, Aspek Hukum Hak} Kekayaan Intelektual, PT. Raja Grafindo Persada, Jakarta 2015.

Sutedi Adrian, hak atas kekayaan intelektuan, Sinar Grafika, Jakarta 2013

Dinas Koperasi dan UKM 2018 


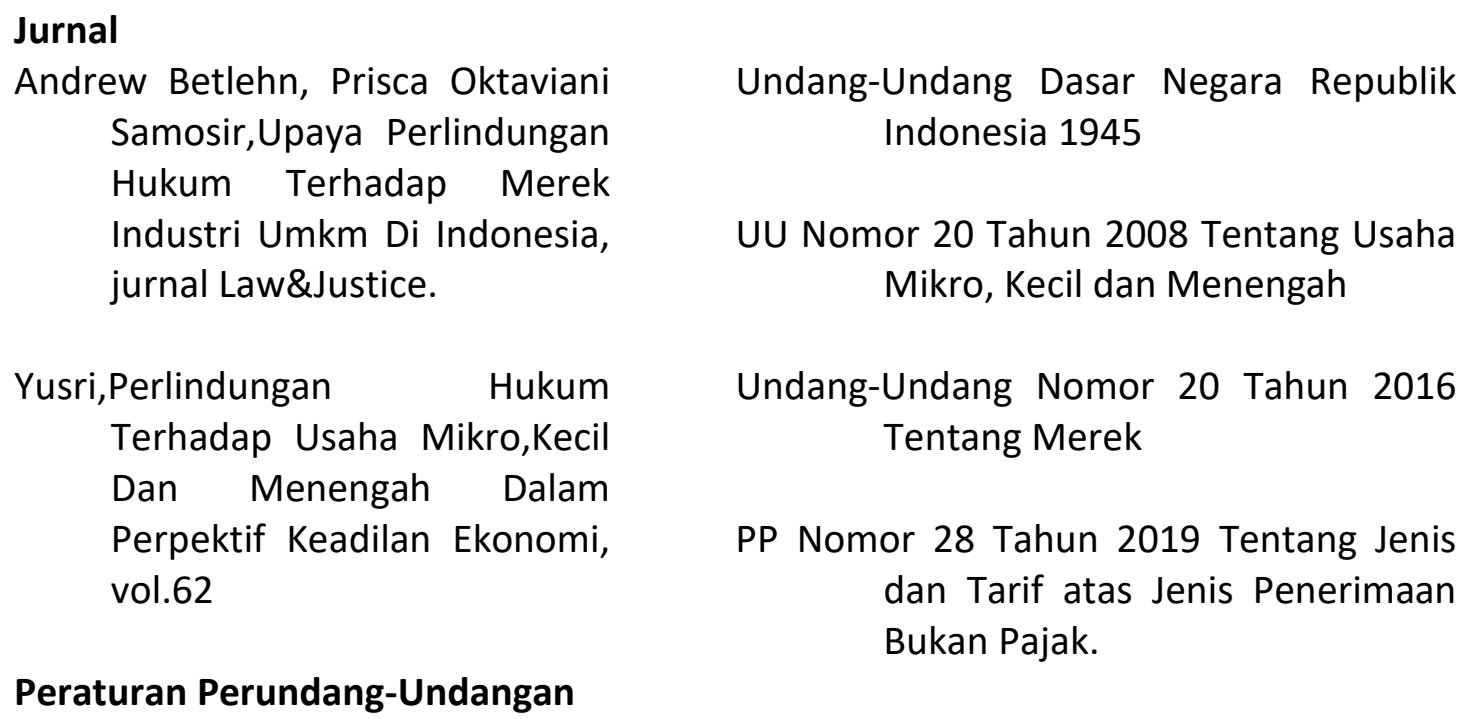

